\title{
SEROLOGICAL STUDIES ON GROUP-B COLICINES AND ORGANISMS PRODUCING THEM
}

\author{
B. W. Senior* and A. H. Emslie-Smith \\ Department of Microbiology, University of Newcastle upon Tyne
}

P URIFIED colicines have usually proved to be potent antigens (Goebel, Barry and Amano, 1957; Hutton and Goebel, 1962; Barry, Everhart and Graham, 1963; Barry et al., 1965; Hinsdill and Goebel, 1966), and colicines $\mathrm{K}$ and V appear to be indistinguishable from the $\mathrm{O}$ (somatic) antigens of the organisms producing them (Amano, Goebel and Miller Smidth, 1958; Hutton and Goebel). Five strains of Escherichia coli known to produce colicines of the B group have been investigated serologically to determine any possible relationships between their O-antigens and B-colicines.

\section{MATERIAL AND METHODS}

\section{Bacterial strains}

The colicinogenic strains of $E$. coli were of diverse origin: no. CA18 was provided by Professor P. Frédericq of Liége, no. CL139 and K260 were obtained from Dr Y. Hamon of Paris and no. B6 and Y6 were isolated by one of us from the faeces of healthy persons. All five strains are haemolytic and are believed not to possess K-antigens of the A-type (Kauffmann, 1951, p. 156) because capsules have never been demonstrated. A locally isolated strain of $E$. coli (no. 9605), which is resistant to colicine V, was used as the indicator for colicine B, since no. K260 produces both colicines; a mutant strain (no. 9605/B) is specifically resistant to colicine B and was used as a control.

\section{Preparation of " free colicine" and "O-antigen"}

Cultures of the five colicinogenic strains were grown in DLM medium, which contains salts and a dialysate from Difco casamino acids and Oxoid yeast extract (Senior, 1968). After centrifugation, the supernatant yielded "free colicine" and the deposited cells were used for the preparation of "O-suspensions " and, in the case of strain CA18, as a source of extractable "O-antigen".

"Free colicine" was precipitated from culture supernatants by 50 per cent. (v/v) saturated ammonium sulphate, dialysed against distilled water and sterilised by Millipore filtration. These preparations possessed potent colicine activity and were used as antigens for immunising rabbits and in gel precipitation and electrophoresis experiments. O-suspensions for use both as vaccines for immunising rabbits and in agglutination experiments were prepared from packed washed cells by the method recommended by Kauffmann (p. 158) for strains lacking A-antigens. Before their final suspension in formol-saline the cells were washed twice in chilled sterile saline to remove any colicine liberated from them during the heat treatment (Blackburn, 1961; Hinsdill and Goebel).

"O-antigens" were extracted from washed and lyophilised packed cells of strain

Received 1 Apr. 1969; accepted 29 Apr. 1969.

* Present address: Department of Genetics, The University of Leicester. 
no. CA18 with either 6M-urea (Baker, Goebel and Perlman, 1949; Blackburn) or 0.2N trichloracetic acid (TCA) (Freeman, Challinor and Wilson, 1940). The resulting preparations, dissolved in distilled water at a final concentration of $10 \mathrm{mg}$ per $\mathrm{ml}$ and sterilised by Millipore filtration, possessed good colicine activity and were used in gel precipitation experiments. Neither " free colicine" nor " O-antigen" inhibited strain no. 9605/B.

\section{Agglutination and agar-gel precipitation tests}

Agglutination tests were carried out according to the standard Dreyer method and were incubated at $37^{\circ} \mathrm{C}$ for $4 \mathrm{hr}$. Gel precipitation reactions were observed by a microdiffusion method for which 1-mm layers of $0.02 \mathrm{M}$ phosphate-buffered 1 per cent Noble agar $(p \mathrm{H} 7 \cdot 3)$ were prepared on slides. Slides similarly coated with Noble agar or with nutrient agar were used in immuno-electrophoresis or simple electrophoresis experiments with colicine preparations: $40 \mathrm{~mA}$ at $300 \mathrm{~V}$ direct current were applied for $4 \mathrm{hr}$ by means of a no. $6800 \mathrm{~A}$ power pack (LKB Instruments Ltd, South Croydon).

\section{RESULTS}

\section{Agglutination experiments}

O-suspensions of each colicinogenic strain were tested for agglutination with two sets of antisera, those prepared against O-suspensions and others against " free colicine" preparations: the results are summarised in tables I and II. Each antiserum agglutinated at high titre only suspensions of homologous cells belonging to the strain from which the immunising agent, cells or colicine, had been derived. Some low-titre heterologous agglutination occurred, but this was frequently asymmetrical and followed no consistent pattern, suggesting that it did not result from an antigenic relationship between the strains, but might have been due to the presence of adventitious agglutinins in the rabbits or to some instability of the bacterial suspensions. The individuality of each strain, however, and a close relationship between colicine and corresponding $\mathrm{O}$-antigen are clearly demonstrated.

\section{Immuno-precipitation experiments}

The strain specificity, and the relationship between colicine and O-antigen, were confirmed by agar-gel precipitation tests. Lines of precipitate formed only when antisera to "O-suspension" or " free colicine" diffused against homologous preparations either of "free colicine" or "O-antigen " obtained by extraction of washed cells. In systems that included colicine and both homologous antisera, the linear precipitates coalesced in typical reactions of identity. "Free colicine" from strain CA18 and "O-antigen" extracted with either urea or TCA gave reactions of identity when tested together with homologous antisera. Colicine preparations that had been absorbed with cells of the sensitive strain no. 9605 gave no precipitate on subsequent testing against homologous antisera.

\section{Electrophoresis experiments}

The intimate relationship between O-antigen and colicine B was further demonstrated by electrophoresis. After electrophoresis of the colicine in a thin 
layer of nutrient agar, the indicator strain no. 9605 was inoculated on the surface and grew everywhere except over an ellipsoidal area on the cathode side of the reservoir into which the colicine had been placed. In parallel immuno-electrophoresis experiments in buffered Noble agar, antisera to homologous colicine and O-suspensions were placed in longitudinal marginal troughs and lines of precipitate formed in positions corresponding to those areas on the nutrient agar preparations where growth of the indicator strain was inhibited.

\section{TABLE I}

Agglutination of $O$-suspensions of strains of Escherichia coli that produce colicine $B$ by homologous and heterologous O-agglutinating antisera

\begin{tabular}{c|r|r|r|r|r}
\hline & \multicolumn{4}{|c}{ Titre of agglutination* of strain by rabbit antiserum made } \\
with boiled cells of $E$. coli strain no. \\
$\begin{array}{c}\text { Heated bacterial } \\
\text { suspension of } \\
\text { strain no. }\end{array}$
\end{tabular}

* Serum dilution giving standard agglutination.

$0=$ No agglutination at a dilution of 1 in 25 .

TABLE II

Agglutination of $O$-suspensions of strains of Escherichia coli that produce colicine $B$ by antisera prepared against homologous and heterologous colicine preparations

\begin{tabular}{|c|c|c|c|c|c|}
\hline \multirow{2}{*}{$\begin{array}{l}\text { Heated bacterial } \\
\text { suspension of } \\
\text { strain no. }\end{array}$} & \multicolumn{5}{|c|}{$\begin{array}{l}\text { Titre of agglutination* of strain by rabbit antiserum made } \\
\text { with colicine from } E \text {. coli strain no. }\end{array}$} \\
\hline & CA18 & CL139 & $\mathrm{K} 260$ & B6 & Y6 \\
\hline $\begin{array}{c}\text { CA18 } \\
\text { CL139 } \\
\text { K260 } \\
\text { B6 } \\
\text { Y6 }\end{array}$ & $\begin{array}{r}5000 \\
0 \\
250 \\
50 \\
0\end{array}$ & $\begin{array}{r}50 \\
2500 \\
250 \\
0 \\
0\end{array}$ & $\begin{array}{r}0 \\
0 \\
5000 \\
0 \\
0\end{array}$ & $\begin{array}{r}50 \\
0 \\
125 \\
2500 \\
25\end{array}$ & $\begin{array}{r}50 \\
0 \\
250 \\
25 \\
1250\end{array}$ \\
\hline
\end{tabular}

* Serum dilution giving standard agglutination.

$0=$ No agglutination at a dilution of 1 in 25 .

\section{Discussion}

Although the B-colicines from different bacterial strains have identical spectra of activity (Senior, 1968), they may be differentiated by serological methods, and their antigenic behaviour is indistinguishable from that attributed to the O-antigens of the strain that produced them. Cell-free colicine preparations were agglutinogenic and cell-free $\mathrm{O}$-antigen preparations possessed colicine 
activity; moreover, the O-antigenicity could not be separated from the bactericidal property either by electrophoresis or by absorption on to susceptible cells. They thus resemble colicines K and V (Goebel et al., 1957; Amano et al., 1958; Hutton and Goebel, 1962; Hinsdill and Goebel, 1966). Antigenicity and colicine activity are probably properties of different parts of the same lipocarbohydrate-protein complex, and the observed facts would satisfy a hypothesis that a common bactericidal protein is conjugated with different strainspecific haptenic factors. Such differences have been described by Hinsdill and Goebel in colicine-K molecules elaborated by antigenically different strains under the direction of a single col factor. Analogous findings were reported by Barry et al. (1965) for antigens of strains producing colicine A.

\section{SUMMARY}

Colicines of group B produced by antigenically distinct strains of Escherichia coli may themselves be distinguished one from another antigenically. On the evidence from agglutination and precipitation experiments the antigenic behaviour of different B-colicines cannot be distinguished from that attributed to O-antigens of the bacteria producing them in culture. Attempts to separate individual factors for these antigenic and bactericidal properties were unsuccessful.

This work was carried out during the tenure by B.W.S. of an SRC Studentship.

\section{REFERENCES}

Amano, T., Goebel, W. F., ANd Mlller 1958. J. Exp. Med., 108, 731. SMIDTH, ELIZABETH

Baker, E. E., Goebel, W. F., ANd Perl- 1949. Ibid., 89, 325. MAN, E.

Barry, G. T., Everhart, D. L., Aвbott, 1965. Zentbl. Bakt. ParasitKde, Abt. I, Orig., V., AND GRAHAM, M.

Barry, G. T., Everhart, D. L., AND 1963. Nature, Lond., 198, 211. GraHAM, M.

BLACKBURN, T. H. . 1961. M.Sc. Thesis, Trinity College, Dublin.

Freeman, G. G., Challinor, S. W., AND 1940. Biochem. J., 34, 307. WILSON, JOYCE

Goebel, W. F., Barry, G. T., AND 1957. Science, N.Y., 126, 1231. AMANO, $T$.

Hinsdill, R. D., AND Goebel, W. F. . 1966. J. Exp. Med., 123, 881.

Hutton, J. J., ANd Goebel, W. F. - . 1962. J. Gen. Physiol., 45, Suppl., p. 125.

KauffmanN, F. . . . . . . . . 1951. Enterobacteriaceae, Copenhagen.

SENIOR, B. W. . . . . . . . . 1968. Ph.D. Thesis, Univ. Newcastle upon Tyne. 